\title{
Service Innovation in Public Sector : A Case Study on PT. Kereta Api Indonesia
}

\author{
Grisna Anggadwita*, Wawan Dhewanto \\ Bandung Institute of Technology, Indonesia \\ *grisna@sbm-itb.ac.id
}

\begin{abstract}
Innovation is an important key for an organization to win the market competition, both in aspects of organization, culture, and business to produce an excellence service and product. Service innovation has been developed to respond quickly the demand of society that increasingly aware of the importance of quality service. PT. Kereta Api Indonesia (KAI) as one of the Indonesian state-owned companies engaged in public transportation made a breakthrough by launching a service product innovation, purchasing system of train tickets and new trains. This paper analyzes the types of service product innovation, success factors of innovation, and explore the barriers of innovation. This study used qualitative methods based on review of the innovation management literature and semi-structured interviews. The role of leadership has an important influence in shaping the behavior of the organization. These organizational learning concepts are used to gain a dynamic of service innovation, it suggests that the company should still perform improvement processes in developing service innovation to meet the challenges faced.
\end{abstract}

Keywords: Innovation; Public Service Innovation; PT. KAI; qualitative method; leadership

\section{Introduction}

Innovation should become a core activity in the public sector: it helps public services to improve performance and increase public value; respond to the expectations of citizens and adapt to the needs of users; increase service efficiency and minimise costs (Mulgan \& Albury, 2003) . Public sector tend to be reluctant to develop innovations compared to the business sector, the condition is triggered by the lack of reward factor, performance measurement and achievement tend to be objective, so it does not motivate individuals to accomplish or performs better (Suwarno, 2008). In order to improve the condition, it is necessary to change management system by establishing mindset that innovation is key to the success of an organization to survive and win the competition not only in the business sector but in the public sector as well. Service industries are a sector that has grown quite large and rapidly in developing countries. In Indonesia, the services sector contributed 48 percent of GNP while the manufacturing sector accounted for 26 percent, agriculture 13 percent, mining and quarrying 7.8 percent [CBS, 2012]. The services sector consists of hotels and accommodation, transportation and communication, real estate and business services. In 2012, transport and communication services sector contributed 10 percent to the GNP in Indonesia [CBS, 2012].

In response to the growth of the service sector, academic interest in the management of service companies has also grown (Johnston, 1999). Opportunities to make a particular service product innovation is still quite large. By developing innovation, especially in the service sector has considerable potential to contribute to economic growth. Studies on innovations in the service sector have received little attention from academic researchers (Johne \& Storey, 1997; de Brentani, 2001). PT. KAI as the largest operator in Indonesia rail freight services provider made a breakthrough by releasing a number of innovations in the field of product services. The success has been widely recognized and enjoyed by the public, especially users of railway services. PT. KAI has proven to all stakeholders the development and continuous product innovation as a manifestation of concern for the management of PT. KAI in terms of improved service because service is basically a corporate paradigm to create a lasting value for customers through products and services. Research on new product development and innovation in public sector has lagged behind similar investigation in the manufacturing sector. The objective of this study is to analyze the different types of service product innovation in the public services sector especially in PT. KAI as an operator of rail services provider, success factors of innovation, and explore the barriers of innovation. 


\section{Literature Review}

Service Innovation in the Public Sector: Innovation in the public sector has been defined as "the creation and implementation of new processes, products, services and methods of delivery which result in significant improvements in the efficiency, effectiveness or quality of outcomes" (Mulgan \& Albury, 2003). In other words, innovation is a process of generating ideas to create or improve the performance of the products and services that are beneficial result for the community. Innovation is a tool for achieving the purpose, to create an innovation in an organization must be a synergistic relationship between leadership, management, human resources, and technology. Compared to the businesses sector, the public sector usually exist within a more complex social system, with goals and values that are more ambiguous and difficult to quantify (Lewis \& Hartley, 2001; Denis et al, 2002; March \& Olsen, 1989). Innovation is very useful to build up the reputation and image of the government in providing public services, public services now tend to provide lower quality than private companies that provide services in the same field (Lekhi, 2007). With service innovation in the public sector provides considerable opportunities for economic growth, and attract investors to cooperate, nowadays people are getting smarter to choose a good service, high quality demands as a result of the conditions and needs of a diverse society, convenience and comfort in getting service. Contributions of research in service innovation has resulted in an extensive literature in new product development in the field of services. Avlonitis et al. (2001) focused on service products to determine the degree of innovations in service companies. The result of innovation in service companies is often referred to as a service product or simply as a product even though most tend to be intangible (Oke, 2004). The term "service products innovation" describes an innovation in service companies.

\section{Innovation Sucess Factors}

Leadership: The role of a leader is very large as the driver in an organization (Wong \& Cha, 2008). President director as chief executive has an important role in creating a process and environment that encourages the birth of creative ideas. A leader must be able to build staff ' trust, introduce process improvements, empower staff for taking the initiative, build cooperation across units, spread of the company's knowledge, and reduce the resistance to change in the early stages of innovation adoption. The main function of the executive leadership team is to create policies and procedures to facilitate innovation, provide the learning facilities both internal and external, and encourage leadership and innovation at all levels in an organization. Good leadership and innovation has the dimensions of a topdown, bottom-up and horizontal (Cook, Matthews, \& Irwin, 2009).

Management / Organizations: In an organization, setting the vision, mission, strategy and values of the organization is essential to form the identity and culture of the organization. Organization must have a culture and climate that spurs the development of innovation and able to continue learning adapt with the changing environment. Organizations should also be able to appreciate and realize the ideas generated. Building an innovative organization should have a set of human resource development, information technology, policy development and program of implementation strategies (Cook, Matthews, \& Irwin, 2009). The process for doing this such as gives responsibility to the staff, the establishment of task forces, working groups, steering committees and networks utilizing internal and external contributors (Cook, Matthews, \& Irwin, 2009). The main challenge in developing organizational innovation is the need to maintain key business functions such as the priority of empowerment existing resources.

Risk Management: Risk management is a fundamental feature of the innovation process. Risk is measured by a combination of consequences and likelihood, the risk is characterized by uncertainty. To facilitate innovation it is necessary to identify risk management, policies and procedures taken under consideration and the information available. Culture of risk aversion in the public sector have been identified that could prevent innovation (Mulgan \& Albury 2003). Faced the risk will be better than avoiding because will stifle innovation. Application of risk management procedures is an important part of the decision making process and should be 'fit for purpose'. That is, the level of supervision and specific mitigation activities must be commensurate with the complexity, value and sensitivity associated with a particular innovation cycle (Cook, Matthews, \& Irwin, 2009).

Human Capital: In conducting the innovation, the potential of human resources qualified and competent in their field is necessary to be able to respond the market competition, not only the information 
technological necessary but also the encouragement and commitment of all organizational personnel. The key elements of the strategy of human capital is a company's recruitment process, retention, training and development of staff (Cook, Matthews, \& Irwin, 2009). Training and development of staff is an opportunity to increase the capacity of innovation in an organization. The need to identify the skills of employees as the best resources should be a priority of the company. Some of the staff development program including formal training, on-the-job training, mentoring, and benchmarking. In addition, communication sessions are also held to educate staff about organizational change.

Technology: The use of highly developed information technology in society, so by utilizing these technological advancements simplify company management in the process of diffusion of innovation to society. Utilizing the information technology enhances the development of service product innovation (Wong \& Cha, 2008). Technology is a tool between service providers and service users, it provides convenience to the user to access information about the companies.

Types of Innovation in Public Sector: Mulgan and Albury (2003) describe three types of innovation:

- Incremental innovations (which shade close to 'continuous improvement', and are thus a more vague definition of innovation)

- Radical innovation: a new service, product, mode of delivery, etc

- Systemic innovation: large-scale and fundamental institutional change.

An incremental innovations will build on existing knowledge and improve resources in a company, which means it will improve competence. While it only make changes with simple technology with the products result to remain competitive in the market. On the other hand, a radical innovation requires knowledge and resources that are completely new. Radical innovations utilize technological advances and deliver products that could win the market competition.

The Barriers of Innovation: Every innovation created will not be apart of the barrier factors. We have identified some barriers and suggest some ways to overcome or reduce (Mulgan \& Albury, 2003). One of the most dominating factor is risk aversion, where workers and the public tend to be familiar with the existing system and do not like the change because it deals with the risks to be faced. The public sector, especially the employees are less likely to relate to the risks and chose to carry out the administrative work of the procedural-with minimal risk (Suwarno, 2008). Moreover, the dominant figure can be prohibitive of the emergence of innovation when the figure is resistant to change, because it will automatically be followed by his followers. The reward for innovation that produced by individual or group is also likely to be less, so people tend to just do the routine without indicating the potential ability to innovate. Giving rewards or incentives to innovators is a factor supporting the emergence of a variety of innovations in the public sector. Factors other barriers are budget constraints with short duration, and convoluted administration make the innovation system to be inflexible (Suwarno, 2008). The barrier factors can be overcome with a structured organizational management, the role of the leadership is very influential in the formation of organizational behavior in the face barriers of innovations.

Figure 1: Potential Barriers to Innovation (Source: Mulgan \& Albury, 2003)

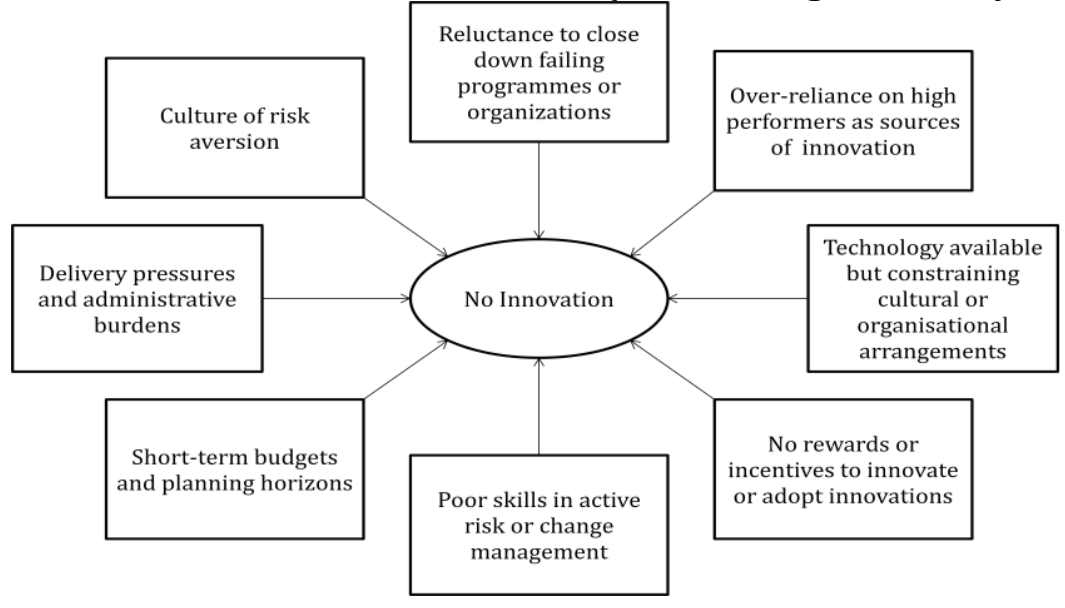




\section{Methodology}

Previous studies in service sector innovation management can be grouped into two playing methodologies: qualitative research (Haaroff, 1983; Garden-Ellison et al., 1986; Johne, 1993; Edvardsson et al., 1995) or survey research (Drew, 1995; Atuahene-Gima, 1996; Cooper, 1998). Qualitative research, by generating richer and more elaborate information about the phenomenon under investigation, can be used to overcome the limitations of quantitative research and vice-versa. This study used a qualitative methodology, by conducting interviews to clarify the concepts identified in the innovation management literature and analyze of information data provided by PT. KAI. Interviews were conducted with junior manager of public relations and verifications manager of PT.KAI. The interview selection is consistent with their job description that provide information needed by the public and its responsibilities include developing new products and services within the organization. Interview questions based on a review of the management of innovation literature and semi-structured interviews. Interview covers topics related to the understanding of the meaning of innovation, types and innovation in service companies, management practices used to develop innovations and processes to manage innovation and people. PT. KAI provides flexibility of data contains information on the development of innovation to improve the validity of the study. Interviewing two key informants in the company increased the internal validity and reliability of research. Interviews confirmed the results of the literature relating to the type of innovation, innovation management practices and service innovation in PT.KAI. The first informant have an understanding of the types of innovations, and the process of innovation itself. Next informant provided information about the results of the innovations that have been done by PT. KAI.

\section{Findings}

KAI is a leading train service providers made a new breakthrough in the last three years. It took PT. KAI to reach the State Owned Enterprise Award 2012. Three keys to success in the field of innovation management at PT. KAI has produced the changes in the workings of the organization or governance of the company. The success of innovation management is focused on improving services for users of rail services in the economic and social development, namely:

- Being able to change the bad image of rail transport all this time both in the public and government eyes in the pessimism of society and government towards rail transport.

- Increasing the profitability of the company (before 2009, PT. KAI loss) and service for all stakeholders, comfort for service users and visitors trains, as well as increasing public confidence and government against PT. KAI.

- On the internal side, the change of work patterns and governance of the organizations better make of management policy gaining widespread support from the employees of PT KAI at all levels.

\section{Service Product Innovations}

\section{Service Product Innovation and Purchasing of Train Tickets}

Reservations and Ticket Purchases via the Agent Host to Host: PT. KAI provides convenience to the passengers to get tickets, ticket sales system that is no longer centered on the station allows all people in Indonesia could easily get a ticket. The program is a collaboration between PT KAI with another company that has its own payment system. Agent host to host owned by PT. KAI are Indomaret, Alfamart, Post Office, Fastpay outlets, and others scattered throughout Indonesia. After payment, the passenger will receive a further payment receipt redeemable at the station nearest to get a train ticket. The positive impacts of the Agent Host to Host is making the station a more orderly and neat because the density of the queue at the counter can be reduced.

Reservations and Ticket Purchases via Internet: Another convenience provided by PT. KAI is the ease of getting tickets through the internet. The rapid technological advances that make it easier for passengers to get tickets through the official website of PT. KAI is www.kereta-api.co.id, they not only get information on purchasing tickets but seat availability. All can be done in one time with ease and save time.

Purchasing Tickets through Railbox: The latest innovation launched by PT. KAI is Railbox. Railbox is a train ticket vending machine that placed at several stations. By using a railcard, which is a prepaid card, customers can purchase a train ticket in the machine railbox. Railcard which is also as identity cards 
membership of Kereta Api Frequent Passenger (KAFP), is a loyalty program as the appreciation of the PT. KAI to loyal customers. Railcard give ease for customers who do not carry cash. Railcard and Railbox answered customer needs for making the purchase of tickets is becoming easy and practical. The prospective passengers only need to stick railcard on railbox, then follow the instructions indicated on the monitor to buy train tickets.

Purchasing Tickets via Drive Thru at Some Stations: Drive Thru is an additional service product for the user such as ticket booking services in the vehicle, so that passengers who have high mobility can purchase train tickets without parking or out of the vehicle. Simply go to the drive-thru lane and the booth will serve quickly. For now the service ticket Drive Thru is available at Gambir Station, Cirebon, Tawang, Semarang, Pasarturi Surabaya and other stations will soon follow. The service Drive Thru is very saving time for passenger.

Purchasing Tickets by Phone (Tap Izy): PT KAI cooperation with PT Telkomsel provides convenience to the user of Telkomsel who is also the user of train to get a train ticket. To be able to enjoy the facilities Tap-Izy, the user of simPATI and kartuHALO must first replace the SIM card with a SIM card Tap-Izy in GraPARI. Communities can also purchase prime simPATI which has features Tap-Izy in GraPARI and stores marked Tap-Izy. Its use is easy, just tap the phone to Tap-Izy machines, ticket purchase transaction has occurred. The purchase method of train ticket via mobile phone beat method of payment on the flight, because there is no airline that implements Tap-Izy payment method.

Contact Center (CC) 121: CC 121 is established in 2010. CC 121 is ready to serve the passengers and prospective passengers for 24 hours. For passengers who want to call the CC 121, enough to call 121 from the PSTN or +621-121 from mobile phones. Prospective passengers can do online train tickets reservation, get information about the train journey, the railway station, the remaining seats available on the train, deliver complaint about the services provided by PT KAI, and provide advice and input to be routed to the relevant section in PT KAI.

Tabel 1: Recapitulation customer complaints via CC 121 (Source: PT. KAI)

\begin{tabular}{|c|c|c|c|c|c|c|c|c|c|c|c|}
\hline \multirow{2}{*}{ Category } & \multirow{2}{*}{2011} & \multicolumn{10}{|c|}{2012} \\
\hline & & Jan & Feb & Mar & Apr & Mei & Jun & Jul & Aug & Sep & Oct \\
\hline Complaints Lost & $24 \%$ & $34 \%$ & $47 \%$ & $14 \%$ & $37 \%$ & $20 \%$ & $24 \%$ & $40 \%$ & $19 \%$ & $16 \%$ & $17 \%$ \\
\hline Routes \& Train & & & & & & & & & & & \\
\hline $\begin{array}{l}\text { Schedule (Delay, } \\
\text { Disruption Travel) }\end{array}$ & $13 \%$ & $8 \%$ & $8 \%$ & $16 \%$ & $9 \%$ & $6 \%$ & $6 \%$ & $3 \%$ & $18 \%$ & $8 \%$ & $9 \%$ \\
\hline $\begin{array}{l}\text { Ticketing (Seller } \\
\text { intermediaries tickets, } \\
\text { ticket out, constraints } \\
\text { booking/payment) }\end{array}$ & $29 \%$ & $10 \%$ & $10 \%$ & $23 \%$ & $22 \%$ & $35 \%$ & $28 \%$ & $15 \%$ & $46 \%$ & $25 \%$ & $14 \%$ \\
\hline Infrastructures & $6 \%$ & & $8 \%$ & $11 \%$ & $9 \%$ & $7 \%$ & $7 \%$ & $12 \%$ & $10 \%$ & $16 \%$ & $15 \%$ \\
\hline Service officers & & & & & & & & & & & \\
\hline $\begin{array}{l}\text { (station, crew on } \\
\text { train) }\end{array}$ & $21 \%$ & $13 \%$ & $26 \%$ & $32 \%$ & $23 \%$ & $32 \%$ & $32 \%$ & $30 \%$ & $6 \%$ & $16 \%$ & $23 \%$ \\
\hline Fare & $5 \%$ & & & $1 \%$ & & & & & $1 \%$ & $2 \%$ & $3 \%$ \\
\hline $\begin{array}{l}\text { Website (Page error, } \\
\text { complaints iBook) }\end{array}$ & $3 \%$ & & & & & & $3 \%$ & & & $17 \%$ & $19 \%$ \\
\hline
\end{tabular}

Based on the data obtained above, with all the ease of services provided by PT. KAI made a significant increase in tickets sales. The data of call center showed yet there is a significant reduction in customer complaints, so that still needed improvement in the innovation process. The complaints of losing and ticketing occupy a fairly high rate, the improvement can be done with improve security around the station. For ticket sales process innovation through information technology are still found obstacles, therefore, necessary to the process of diffusion of innovation through the effective and efficient channels, not only through the internet but can via the mass media (television, radio, newspaper, etc.) and supported by information periodically provided by PT. KAI at stations. The officers PT. KAI has an important role in service innovation, because it deals with customer satisfaction in receiving services, all officers are expected to provide the best service, friendly, and oriented towards customers. 


\section{New Trains}

Passenger Trains: PT. KAI has operated passenger trains, both in commercial and non-commercial trains. To commercial train PT. KAI perform various innovations such as the manufacture of new trains, rerouting, or elimination train trips are considered detrimental to the company. Besides making new railway PT. KAI also to innovate by giving a new twist on an existing service products include:

- Installation of air conditioning on the economics class train aims to improve services

- Trains batik which aims to preserve the national culture

- Train for women

- Trains and stations which are smoke-free

Goods Trains: Direction of future development of train business is transportation of goods, it is because still very high potential existing transport both in Java and outside Java. Here are some new system developed by PT.KAI for transport of goods:

- Paletisasi is used to transport cement to facilitate and expedite the loading and unloading, warehousing and increased utility vehicle.

- Transport of coal by using the container system is used to replace the previous system of transport (carriage of bulk), in order to facilitate loading and unloading system with a common loading and unloading (escavator, crane, forklift) and do not need to use the apron feeder

- $\quad$ The carriage of goods by rail flat ease in serving various types of transportation such as Container Transport, Fuel Oil, Cement.

Innovation Success Factor: Here is typologi of success factors by PT. KAI in generating innovation to provide service to the customer. These success factors synergize with each other.

Figure 2: Typology Innovation Success Factors

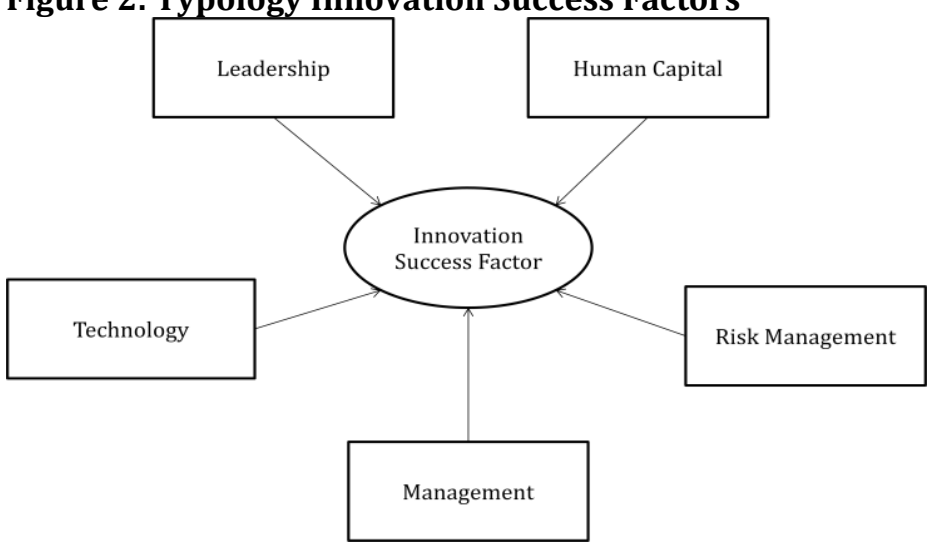

Tabel 2: Success Factor Indicators

\begin{tabular}{|c|c|}
\hline $\begin{array}{l}\text { Innovation Success } \\
\text { Factors }\end{array}$ & Finding \\
\hline \multirow[t]{4}{*}{ Leadership } & Leaders come from a professional and experienced \\
\hline & Able to develop of potential in accordance with the organizational identity \\
\hline & Having paradigm in developing innovation \\
\hline & $\begin{array}{l}\text { Giving an example for the organization he leads by plunging directly give } \\
\text { practices good performance }\end{array}$ \\
\hline \multirow[t]{3}{*}{ Management } & $\begin{array}{l}\text { The new management from professionals who are able to change the work } \\
\text { culture }\end{array}$ \\
\hline & $\begin{array}{l}\text { The use of information and communication technology to accelerate } \\
\text { decision-making and information dissemination }\end{array}$ \\
\hline & $\begin{array}{l}\text { Regular Executive Committee meeting as a breakthrough in performance } \\
\text { evaluation, discussion of strategic issues and corporate socialization }\end{array}$ \\
\hline Risk Management & $\begin{array}{l}\text { Implementation of GCG practice as a whole. With implementation of an } \\
\text { Enterprise Risk Management, GCG is expected to create value of the firm on } \\
\text { an ongoing basis through a pattern of healthy growth in the long term. }\end{array}$ \\
\hline & $\begin{array}{l}\text { PT. KAI also continuously the complete of Risk Register, Risk-Based } \\
\text { Improvement and Application Procedures ERM online for all activities of the }\end{array}$ \\
\hline
\end{tabular}


Human Capital

Technology company. Evaluation of continuous periodically both internally and externally to get sustainability of input and material improvement.

Eliminates seniority

New remuneration system

Online recruitment system and a more pro-active

Changes to the organization from Product Oriented to Customer Oriented and Prioritize Safety

Benchmarking and hospitality

The use of information technology in every service product innovation

The use of information and communication technology to accelerate decision-making, information dissemination, and HR development.

Based on Types of Innovations: Based on the type of innovations, PT. KAI has type incremental to radical. The process of incremental change is marked by several changes to the existing knowledge to upgrade the resource capabilities. Incremental changes are common in the public sector such as PT. KAI, in addition to some fairly radical changes made by PT. KAI, such as remuneration system to improve the performance of their employees. Some radical changes related to service innovation processes such as limiting the number of passengers and giving punishment to passengers who violate rules such as smoking and selling in the area of the station. The amendment aims to provide convenience to its customers, the changes of mindset from target oriented to customer oriented is a main program conducted by the leader of PT. KAI.

Barriers: Another barriers appears that socio-cultural phenomena in society. Some of the identified barriers related to service innovation launched by PT. KAI are:

- Society conditions were very diverse and not least the people of Indonesia who do not understand about information technology

- Brokering practices are still happen

- Bottlenecks in land acquisition process for the manufacture of a new rail route

- The process of habituation to passengers who smoked carelessly and the naughty passengers

- Hawkers who interfere with passenger

- Not all workers are motivated by change of system PT. KAI impact on worker performance degradation

- Constrained of government policies and inhibition of operational funds

\section{Conclusion and Implications}

Innovation is now considered important in the public sector to respond effectively to the challenges posed by social and technological change, and rising public expectations toward public services. PT. KAI as the operator provider of railway transportation services faced competition from other transport modes such as travels, planes, and buses. That makes the PT. KAI is different from other public organizations are innovations constantly being developed to deliver customer satisfactions and focus on increasing the capabilities of staff. Service product innovation launched by PT. KAI aims to provide convenience to customers. Innovations made by PT. KAI is inseparable from the success factors that drive the emergence of innovations. One of the keys to successful PT. KAI transformation is the role of leadership. The executive director prepare program of the organization in the face of great change include changes in the internal and external processes. Open culture is very important to encourage staff in creating new ideas are innovative. Every innovation certainly exist of barriers, the barriers is a challenge for PT. KAI to continue the process of improvement of the services they provide. For the public sector, the commitment of all levels of staff is essential in creating an innovative organization. Provide an opportunity for all levels of staff to participate in creating and implementing organizational change is a form that can foster commitment. Channels of communication among different units within public organizations is also very important in ensuring that innovative ideas disseminated throughout the organization. Risk management is applied by PT. KAI in the face of changes can gradually break away from the image of an adverse risk. This paper is expected to provide an overview to other organizations engaged in the same field about success factors and barriers in creating innovation for sustainability of organizations. 


\section{References}

Atuahene-Gima, K. (1996). Differential potency of factors affecting innovation performance in manufacturing and services firms in Australia. Journal of Product Innovation Management, 13, 3552.

Avlonitis, G. J., Papastathopoulou, P. G. \& Gounaris, S. P. (2001). An empirically-based typology of product innovativeness for new financial services: success and failure scenarios. Journal of Product Innovation Management, 18(5), 324-42.

Central Bureau of Statistics. (2012). Trends of Selected Socio-Economic Indicators of Indonesia. Jakarta, Indonesia.

Cook, G., Matthews, M. \& Irwin, S. (2009). Innovation in the Public Sector : Enabling Better Performance, Driving New Directions, Australia National Audit Office.

Cooper, R. J. (1998). A Multidimensional Approach to the Adoption of Innovation. Management Decision, $36(8), 493-502$.

De-Brentani, U. (2001). Innovative versus incremental new business services: different keys for achieving success. Journal of Product Innovation Management, 18, 169-87.

Denis, J. L., Hebert, Y., Langley, A., Lozeau, D. \& Trottier, L. (2002). Explaining diffusion patterns for complex health care innovations. Health Care Management Review, 27, 60-73.

Drew, S. (1995). Strategic benchmarking: innovation practices in financial institutions. International Journal of Bank Marketing, 13(1), 4-16.

Edvardsson, B., Haglund, L. \& Mattsson, J. (1995). Analysis, planning, improvisation and control in the development of new services. International Journal of Service Industry Management, 6(2), 24-35.

Garden-Ellson, N., Huss, R. A., Levine, J. \& Pierce, W. E. (1986). Key factors in new product success: three case studies. Journal of Retail Banking, 8(1/2), 25-33.

Haaroff, K. (1983). An exercise in product development for the 1980s: international cash management service. International Journal of Bank Marketing, 1(3), 56-68.

Johne, A. (1993). Insurance product development: managing the changes. International Journal of Bank Marketing, 11(3), 5-14.

Johne, A. \& Storey, C. (1997). New service development: a review of the literature and annotated bibliography. Management Working Paper B97/2, City University Business School, London.

Johnston, R. (1999). Service operations management: return to roots. International Journal of Operations \& Production Management, 19(2), 104-24.

Lewis, M. \& Hartley, J. (2001). Evolving forms of quality management in local government: lessons from the Best Value pilot programme. Policy and Politics, 29, 477-496.

Lekhi, R. (2007). Public Service Innovation, This research report was prepared by Research Republic LLP for The Work Foundation's Knowledge Economy Programme.

March, J. G. \& Olsen, J. P. (1989). Rediscovering Institutions: The Organizational Basis of Politics. New York: The Free Press

Mulgan, G. \& Albury, D. (2003). Innovation in the Public Sector, Strategy Unit, Cabinet Office.

Oke, A. (2004). Innovation types and innovation management practices in service companies. International Journal of Operations \& Production Management, 27(6), 564-587.

PT. Kereta Api Indonesia (Persero). (2012). The State Owned Enterprise Award 2012 Presentation Materials, Bandung, Indonesia. http://www.kereta-api.co.id.

Suwarno, Y. (2008). Inovasi di Sektor Publik, STIA-LAN Press, Jakarta, Indonesia.

Wong, P. \& Cha, V. (2008). Service Innovation in Public Sector - A Case Study on The National Library Board, National University of Singapore. 